\title{
Antibiotics resistant Escherichia coli isolated from aquatic ecosystems in Palembang, South Sumatra, Indonesia
}

\author{
MARIESKA VERAWATY", NITA APRIANI, LELY RASTI TARIGAN, ENDAH TRI APRIAN, \\ WEMONA CHARISSA LAURENTA, MUHARNI \\ Department of Biology, Faculty of Mathematics and Natural Sciences, Universitas Sriwijaya. Jl. Raya Km. 32, Inderalaya 30662, Ogan Ilir, South \\ Sumatra, Indonesia. Tel.: +62-711-580268, Fax.: +62-711-580056, `email: marieskaverawaty@unsri.ac.id
}

Manuscript received: 17 October 2019. Revision accepted: 7 December 2019

\begin{abstract}
Verawaty M, Apriyani N, Tarigan LR, Apriyan ET, Laurenta WC, Muharani. 2020. Antibiotics resistant Escherichia coli isolated from aquatic ecosystems in Palembang, South Sumatra, Indonesia. Biodiversitas 21: 86-97. Antibiotics-resistant bacteria (ARB) are one of the emerging water contaminants currently gaining serious global concern due to their adverse risk to ecosystems, wildlife, and public health. This study determined antibiotics resistant Escherichia coli isolated from aquatic ecosystems in Palembang. Most probable number (MPN) was used for bacterial estimation and the Kirby-Bauer method was used for susceptibility test against antimicrobial agents. The results indicated that $82 \%$ of E. coli isolates from 28 sampling sites were resistant to ampicillin, $57 \%$ to tobramycin, and $71 \%$ to tetracycline. The isolates showed intermediate profile to kanamycin (50\%), $57 \%$ to cotrimoxazole, $50 \%$ to cefixime, and 54\% to gentamycin. These isolates still showed sensitivity towards ciprofloxacin (86\%) and chloramphenicol (61\%). Total coliform (TC) numbers ranged from 0 to $>1600 \mathrm{MPN} / 100 \mathrm{~mL}$. Sampling sites with high MPN values of $\geq 1600 \mathrm{MPN} / 100 \mathrm{~mL}$ were Sekanak watersheds (SW1, SW8, SW11, SW12, SW13, and SW14) followed by SW2 and SW9 with a value of 1600 MPN/100 mL, while samples from cattle and fish farms (CW) varied from 0 to $170.000 \mathrm{MPN} / 100 \mathrm{~mL}$. TC of samples collected from retention ponds (RP) ranged from 0 (RPJSC) to $1.600 .000 \mathrm{MPN} / 100 \mathrm{~mL}$ (RPSH3). The Escherichia coli (EC) counts varied from $1.7 \times 10^{3}$ (RPSH2) to $\geq 1.6 \times 10^{4} \mathrm{MPN} / 100 \mathrm{~mL}$ (SW11, SW12, SW13, and SW14). Several samples (SW3, RPPI, RPTS, RPSB, RPIBA, and RPOPI) have no E. coli. The results indicated some of the sampling locations that exceeds the quality standard of water have been regulated by the Governor of South Sumatra and the Indonesian Government.
\end{abstract}

Keywords: Escherichia coli, antibiotics resistant bacteria, aquatic ecosystems

\section{INTRODUCTION}

Fecal coliform is an indicator of contamination of human or animal feces in water bodies. If fecal coliform is in high concentration in a site, it is very likely that pathogenic organisms are also present (Mishra et al. 2018). Understanding emerging contaminants in the water are important because water is the link among the four major ecosystems-human, animal, soil, and aquatic-involved in the circulation of antibiotic resistance (Nwosu, 2001; Baquero et al. 2008). Currently, antibiotic-resistant bacteria (ARB) are becoming one of the emerging water hazards (Pruden et al. 2006; Taylor et al. 2011). Aquatic ecosystems play an ecological and evolutionary role in driving the persistence emergence and spread of antimicrobial-resistant (AMR) microorganisms (Taylor et al. 2011). A study was done by Ribeiro et al. (2012) showed Escherichia coli antibiotic resistance patterns and its groundwater contamination origin in France, this study contributed to the understanding of the emerging issue. Wang et al. (2019) recently suggested that horizontal gene transfer (HGT) is one of E. coli capabilities potentially harm our ecosystem, wildlife, and public health; especially its prevalent in biofilms and sediment, this is due to its ability on genetic exchange with potential to increase the spread of environmental pathogens. They also suggested it has been more ARB and antibiotics resistant genes (ARGs) were detected in residential than in hospital wastewater ( $\mathrm{Li}$ et al. 2015), nanomaterials (Qiu et al. 2012), disinfectants (Guo et al. 2015), disinfection by-products (Li et al. 2016) and ionic liquids (Luo et al. 2014); the ionic liquid is suggested taking roles in the spread of ARGs by promoting HGT. The genetic material in resistant microorganisms can be passed from one to another and create unavoidable spreads of contamination. Jain (2019) reported that the Ganga river had been polluted by a large number of resistant antibiotics bacteria which was suspected from some waste discharged from households, drug manufacturing units, hospitals, and poultry industries. Another study was done by Cho et al. (2018) suggested that the other possible human's coliform sources include sewage leaks, failing septic tanks, municipal, residential, medical, and industrial waste facilities and also animal sources include runoffs from animal farms, land application of animal manure, pet wastes from parks, and wildlife; all of them are potentially increase the spreads of the hazardous contaminants.

The increased spread of bacteria that are resistant to several types of antibiotics or "superbugs" can be due to various human activities such as excessive used of antibiotics in human, livestock and fish farming, poor infection control in health care systems, poor hygiene and sanitation in developed and developing countries which resulted in approximately 700.000 deaths each year 
(Guyomard-Rabenirina et al. 2017). Antibiotic resistance causes hundreds of thousands of deaths annually (Review on Antimicrobial Resistance 2014), so this is a major global health threat with an increasing trend (WHO 2014). Ballantyne (2007) suggested that some of today's human activities potentially trigger the AMR such as some households' antibacterial contained products, and antibacterial agent such as triclosan is reported as one of the stressors that potentially develop bacterial defense and tolerance for their survival and antibiotics resistant community reproducibility through cross-resistance and genetic mutations.

Coliform is known as one of the largest groups of bacteria in bacterial polluted water (Mishra et al. 2018). In some countries, where the incidence of antibiotic resistance among both coliform and fecal coliform bacteria from seawater and shellfish samples is high, the coliform bacteria are regarded as dangerous pollution indicators (Grabow et al. 1974). Regular monitoring of coliform levels in the environment provides the status of water potability, warns prior incidence of various public health concerns, and paves the way for designing remedial measures (Mishra et al. 2018). Currently, prevalence of multi-drug resistance in the coliforms triggered by the increasing of antimicrobials used in household, clinical, veterinary, animal husbandry and agricultural settings including from fertilized fields that lead to more severe and complex antibiotic contamination is current global concern; therefore, the potential antibiotic contamination sites require additional attention (Zhang et al. 2014). High incidence of antibiotic resistance among gram-negative bacteria due to the widespread and uncontrolled used of antibiotics in agriculture and medicine has been documented (Anderson 1968; Richmond 1975). The evidence of antibiotic-resistant coliform from effluents and land runoff enter marine receiving waters has also been reported (Smith 1970, 1971; Grabow et al. 1974). Antimicrobial agents are currently widely used to promote growth and disease control in animals. The number of veterinary antibiotics (VAs) reaching 105-106 tones annually (Levy 1998; Sarmah et al. 2006; Li et al. 2013), and antibiotics that poorly absorbed in the animal gut can cause around $40-90 \%$ of the antibiotics excreted via urine or feces in the form of origin compounds or metabolites (Kumar et al. 2005; Gutiérrez et al. 2010). The residue of VAs in animal wastes has been widely reported (MartinezCarballo et al. 2007; Zhao et al. 2010; Motoyama et al. 2011; Pan et al. 2011; Li et al. 2013). Evidence of hospital settings and the retail food supply as the sources of the spread of antibiotic resistance enteric bacteria (Gorbach 2001; Karlowsky et al. 2003; Edge and Hill 2005) and those emerging contaminants enter and spread in the rivers and lakes which are served as sources of drinking water, recreation, or irrigation.

According to Mishra (2018), antibiotics entered and dispersed into our environment through seepages, sewages, clinical or agricultural settings runoffs and it can create antibiotic resistance genes pools. Their presences in below minimum inhibitory concentration (MIC) affect their transfer, assimilation, and propagation caused multiple antibiotic resistances (MAR) index of bacterial isolates from environment. Some studies describe the possible origin of the antibiotics and antibiotics resistant genes (ARGs) in the environment; and suggested there is a relationship between anthropogenic contamination with residual antibiotics (RAbs) that spread, accumulate and disseminate in the aquatic environments (Baquero et al. 2008; Gillings 2013). ARGs in the aquatic environments correlate with human activities and antibiotic usage (Pei et al. 2006; Pruden et al. 2012; Khan et al. 2013). Furthermore, antibiotic usage in humans, veterinary medicine, and the pharmaceutical industrial sites, especially their wastes, are responsible for the increasing prevalence of antimicrobial-resistant bacteria (AMRB) (Holmberg et al. 1987; Cheng et al. 2012; Adegoke et al. 2017).

Awareness of the potential contaminants in the aquatic environment in Palembang that can threaten the ecology of the city, public health, and wildlife is urgently needed, and the river as one of the water resources for the city water supply has to be maintained for its sustainability. Therefore, this study aimed to investigate the potency of antibiotic resistance in $E$. coli isolates from aquatic ecosystems in Palembang. This information is expected to contribute to the understanding of antibiotic resistance in the aquatic environment and the potential environmental and public health risks associated with them. The current study aims to highlight the alarming issue of the prevalence of multiple antibiotic-resistant $E$. coli in the aquatic system of Palembang, which is a potent environmental and public health concern.

\section{MATERIALS AND METHODS}

\section{Sampling locations}

Surfaces water samples for microbiological assays were collected from 41 sampling sites, i.e., cattle and fish farms, retention ponds, and non-point sources of domestics disposal along Sekanak River watersheds and its tributaries in Palembang City (Figure 1). Samples were collected by a purposive random sampling method from March to May 2018. All samples were collected in sterile containers and immediately placed in iceboxes and maintained at $4^{\circ} \mathrm{C}$ before reaching the laboratory and analyzed directly for measuring biological parameters, while physical and chemical parameters were directly measured on-site as per standard methods for the examination of water and wastewater (APHA 1995). Water quality parameters were measured in situ using a Lutron YK-2005WA instrument; they were water temperature $\left({ }^{\circ} \mathrm{C}\right), \mathrm{pH}$, total dissolved solids (TDS in $\mathrm{mg} / \mathrm{L}$ ), and dissolved oxygen (\% saturation and $\mathrm{mg} / \mathrm{L}$ ). Preserved water samples were analyzed for total Nitrogen ( $\mathrm{N}$ tot in $\mathrm{mg} / \mathrm{L}$ ) (TOC-N-Analyzer-Teledyne Tekmar), total Phosphorus (P tot in $\mathrm{mg} / \mathrm{L}$ ) (SNI 06-24831991), chemical oxygen demand (COD in mg/L) (SNI 6989.2:2009) and total suspended solids (TSS in $\mathrm{mg} / \mathrm{L}$ ) (SNI 06-6989.3-2004). The characteristics of locations of each of the sampling site were presented in Table 1. 

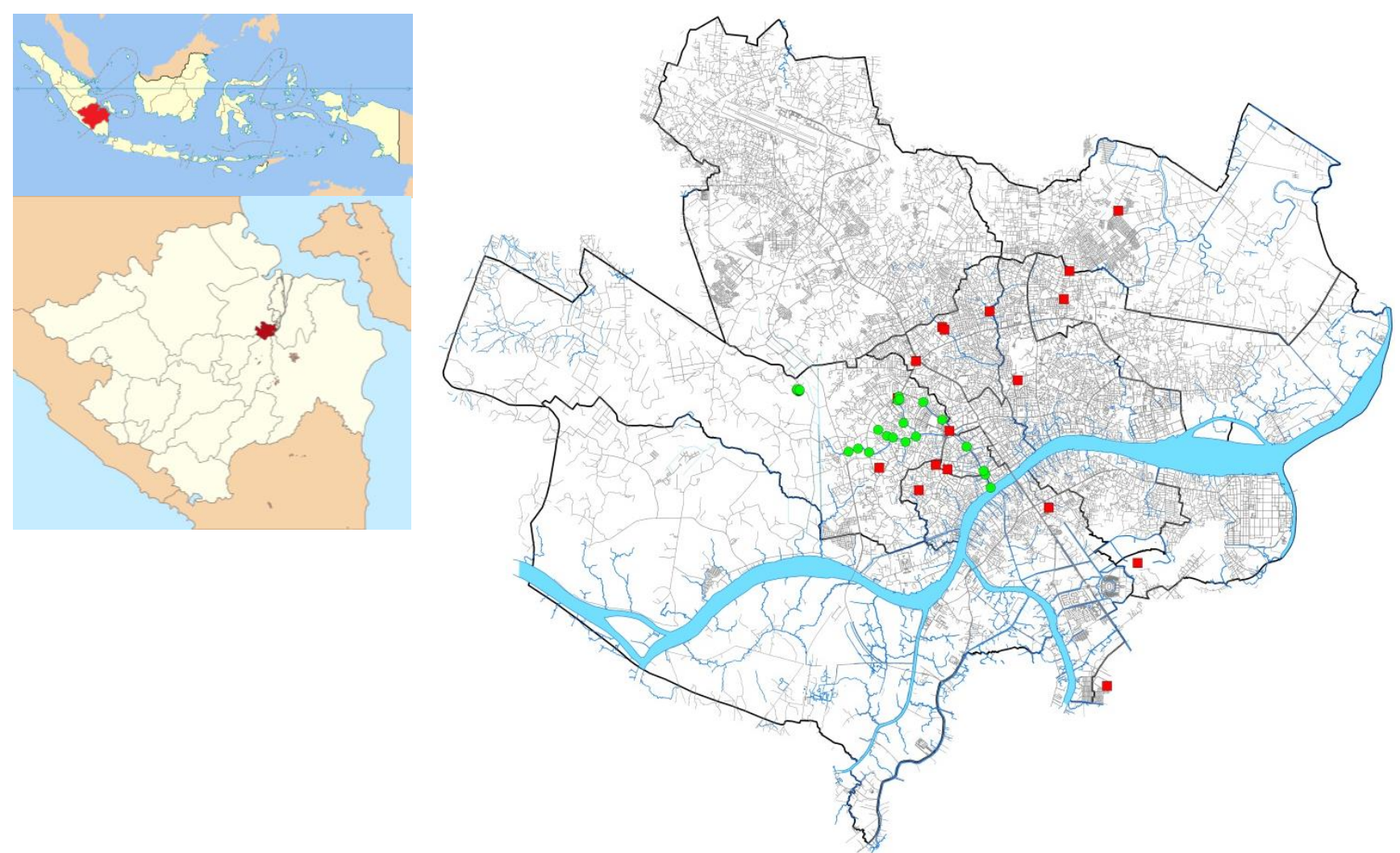

Figure 1. Research locations of water sampling sites in Palembang City, South Sumatra, Indonesia

\section{Total coliform enumeration and Escherichia coli identification}

Most Probable Number (MPN) method was used to estimate the total coliform in water samples according to SNI Method (SNI 2897-2008 and SNI 01- 2897-1992): Presumptive Test was conducted by pipetting $10 \mathrm{~mL}$ water samples from each sampling points to a $30 \mathrm{~mL}$ screw-cap tube ( 5 tubes for each sample) containing $10 \mathrm{~mL}$ of Double Strength Lactose Broth (DSLB). Similarly, add $1 \mathrm{~mL}$ of the same samples to 5 tubes of $17 \mathrm{~mL}$ screw-cap tube containing $7 \mathrm{~mL}$ of Single Strength Lactose Broth (SSLB) and $0.1 \mathrm{~mL}$ of each sample to 5 screw-cap tubes with $7 \mathrm{~mL}$ Lactose Broth Single Strength. All the tubes were incubated at $36 \pm 1{ }^{\circ} \mathrm{C}$ for 48 hours. The number of tubes with the presence of gas formation is the positive presumptive test. Confirmation Test was carried out on tubes that give positive results on Lactose Broth in the presumptive test. The sample showed a positive result was added to a tube containing $10 \mathrm{~mL}$ of Brilliant Green Lactose Broth (BGLB), and then incubated at $36 \pm 1{ }^{\circ} \mathrm{C}$ for 48 hours. The presence of gas in the tube containing BGLB confirms the presence of coliform bacteria in the sample. The number of positive tubes forming gas was recorded. Then the results were compared to MPN tables. Eijkman Test: The Eijkman test is a specific test for identifying fecal coliform at $44-46^{\circ} \mathrm{C}$. It was performed by inoculating the positive culture on the Lactose Broth media into a tube containing EC Broth media in Durham tubes. The tubes were incubated in a water bath at $44-45^{\circ} \mathrm{C}$ for 48 hours
Positive results were indicated by gas formation in the Durham tube, then the samples were determined for the density of thermotolerant fecal coliform. The completed test was performed on positive cultures to determine the presence of $E$. coli by streaking on EMBA plates and then incubated at $36^{\circ} \mathrm{C}$ for 48 hours. Colonies with green metallic sheen were inoculated on the oblique NA medium and incubated at $35^{\circ} \mathrm{C}$ for 24 hours. After the colony grew on the NA media, then IMViC test was done to confirm the presence of $E$. coli. The indole test was done by inoculating the colony in Tryptone Broth media and incubated at $35^{\circ} \mathrm{C}$ for 24 hours. After 24 hours incubation, the indole reagent was added to each tube and shaken for 10 minutes. The crimson ring on the surface showed a positive indole reaction. Methyl Red Test was done by inoculating the colony in NA into the MR-VP Broth and incubated at $35^{\circ} \mathrm{C}$ for 48 hours. After 48 hours, 4 to 5 drops of methyl red were added. The presence of red color showed a positive reaction. Voges Proskauer Test was done by the inoculating colony in NA into the MR-VP. Then they were incubated at $35^{\circ} \mathrm{C}$ for 48 hours. After 48 hours, $0.6 \mathrm{~mL}$ alpha naphthol solution and $0.2 \mathrm{~mL}$ of $\mathrm{KOH}$ solution were added and homogenized then left for 2-4 hours. The positive reaction was indicated by pink to dark red result. Citrate Test was done by inoculating colony in NA into Simmons Citrate Broth and then incubated at $35^{\circ} \mathrm{C}$ for 48 hours. The positive reaction was shown by blue color, and the negative reaction was green color. 


\section{Antibiotics susceptibility test}

Susceptibility tests for antimicrobial agents were conducted using the Kirby-Bauer method according to Clinical and Laboratory Standards Institute (CLSI 2010) and Urase and Sato (2016). All of E. coli strains were prescreened for their ability to form colonies on MuellerHinton agar supplemented with selected antimicrobial agents at the minimum inhibitory concentrations (MICs) listed in the Clinical Laboratory Standards Institute (CLSI, 2010) for Enterobacteriaceae of resistant strains, i.e. tetracycline $10 \mu \mathrm{g} / \mathrm{mL}$, ciprofloxacin $5 \mu \mathrm{g} / \mathrm{mL}$, kanamycin $30 \mu \mathrm{g} / \mathrm{mL}$, cotrimoxazole $30 \mu \mathrm{g} / \mathrm{mL}$, tobramycin $10 \mu \mathrm{g} / \mathrm{mL}$, chloramphenicol $30 \mu \mathrm{g} / \mathrm{mL}$, cefixime $5 \mu \mathrm{g} / \mathrm{mL}$, gentamycin $10 \mu \mathrm{g} / \mathrm{mL}$, and ampicillin $10 \mu \mathrm{g} / \mathrm{mL}$. The strains growing on one or more plates containing antimicrobial agents were examined for their susceptibility to nine antimicrobial agents by the Kirby-Bauer method.

Escherichia coli strains were inoculated in nutrient broth and incubated at $35+2^{\circ} \mathrm{C}$ for five hours. The inoculum was used within 30 minutes of preparation (Andrews (2001). The colonies were touched with a loop, and then the growing colonies were transferred into a sterile broth. The turbidity of suspension was adjusted to a 0.5 McFarland standard (EUCAST 2003). The McFarland standard was prepared by adding $0.5 \mathrm{~mL}$ of $0.048 \mathrm{M} \mathrm{BaCl}_{2}$ $\left(1.17 \% \mathrm{w} / \mathrm{v} \mathrm{BaCl} 2.2 \mathrm{H}_{2} \mathrm{O}\right)$ to $99.5 \mathrm{~mL}$ of $0.18 \mathrm{M} \mathrm{H}_{2} \mathrm{SO}_{4}$ $(1 \% \mathrm{v} / \mathrm{v})$ with constant stirring. Cotton swabs were used for streaking the diluted broth onto Mueller-Hinton agar plates. After air drying, antibiotic discs were placed on agar plates. The plates were inverted and incubated aerobically at $35+2$ ${ }^{\circ} \mathrm{C}$ for 16 to 18 hours. The zone of inhibition was measured and interpreted according to the CLSI (CLSI, 2010). The ATCC strain of E. coli was used as a control strain. Preparations of antibacterial agents were conducted according to EUCAST (2003); the stock solutions were made by using Formula F.1A and F.1B as follows:

(F.1A) weight of powder $(\mathrm{mg})=\frac{\text { volume of solution }(\mathrm{mL}) \mathrm{x} \text { Concentration }\left(\frac{\mathrm{mg}}{\mathrm{L}}\right)}{\text { Potency of powder }\left(\frac{\mathrm{mg}}{\mathrm{g}}\right)}$

(F.1B) volume of diluent $(\mathrm{mL})=\frac{\text { Weight }(\mathrm{mg}) \times \text { Potency }\left(\frac{\mathrm{mg}}{\mathrm{g}}\right)}{\text { Concentration }\left(\frac{\mathrm{mg}}{\mathrm{L}}\right)}$

$$
\text { (F2.) } \quad \mathrm{D}=\frac{(\mathrm{DV}-\mathrm{DC})+(\mathrm{DH}-\mathrm{DC})}{2}
$$

Where:

DV: Vertical diameter

DC: Disk diameter

DH: Horizontal diameter

The diameters (in millimeters) of the clear zones as growth inhibition around the antimicrobial agent diskswere measured following the method described by Sayah (2005). Diameter of the inhibitory zone (two quadrants) were measured according to Formula 2 (F2). Diameter of inhibitory zone was interpreted according to Clinical and Laboratory Standard Institute (CLSI 2012) as follows: ampicillin (sensitive > $17 \mathrm{~mm}$; intermediate: 14-16 mm; resistant $<13 \mathrm{~mm}$ ); tetracycline (sensitive $\geq 19 \mathrm{~mm}$; intermediate: $15-18 \mathrm{~mm}$; resistant $\leq 14 \mathrm{~mm}$ ); cefixime (sensitive > $19 \mathrm{~mm}$; intermediate: $16-18 \mathrm{~mm}$; resistant $<15$ $\mathrm{mm}$ ); chloramphenicol (sensitive $\geq 18 \mathrm{~mm}$; intermediate: 13-17 $\mathrm{mm}$; resistant $\leq 12 \mathrm{~mm}$ ); ciprofloxacin (sensitive $\geq$ $21 \mathrm{~mm}$; intermediate: $16-20 \mathrm{~mm}$; resistant $\leq 15 \mathrm{~mm})$; cotrimoxazole (sensitive $\geq 16 \mathrm{~mm}$; intermediate: 11-15 $\mathrm{mm}$; resistant $\leq 10 \mathrm{~mm}$ ); canamycin (sensitive $\geq 18 \mathrm{~mm}$; intermediate: $14-17 \mathrm{~mm}$; resistant $\leq 13 \mathrm{~mm}$ ); gentamycin (sensitive $\geq 15 \mathrm{~mm}$; intermediate: $13-14 \mathrm{~mm}$; resistant $\leq 12$ $\mathrm{mm}$ ); tobramicin (sensitive $\geq 18 \mathrm{~mm}$; intermediate: $13-17$ $\mathrm{mm}$; resistant $\leq 12 \mathrm{~mm}$ ).

\section{RESULTS AND DISCUSSION}

The sampling sites in this study are presented in Figure 1 and Table 1; namely 18 retention ponds (RP), lake (1 site), seven sites of cattle ranches and fish ponds (CW1CW7) and 15 sampling sites located along the Sekanak River and its tributaries namely Muhajirin River and Baung River (SW1-SW15). Sekanak River is one of the Musi River tributaries, and a tourist center in Palembang, South Sumatra. Some of Palembang residents live surrounds the Sekanak River. The characteristics of the sampling sites are described in Table 1 and presented in Figure 2.

The quality standard of river water quality in South Sumatra has been regulated through South Sumatra Governor Regulation No.16 of 2005, which classified river water into 3 classes based on water quality for its provisions. Also, there was Government Regulation No. 8 of 2012 concerning the quality standards of liquid waste from industrial activities, hotels, hospitals, domestic and coal mining. In this regard, effluent standards for domestic wastewater are further regulated through two products of law at the ministry level; Ministerial Regulation No. 5 of 2014 (Permen No. 5) regulates general quality standards for liquid waste disposals and Ministerial Decree No. 112 of 2013 (Kepmen No. 112) which specifically regulates effluent standards for domestic wastewater. The effluent parameters of domestic wastewater based on the two regulations as follows: pH-6-9, BOD $100 \mathrm{mg} / \mathrm{L}$, TSS 100 $\mathrm{mg} / \mathrm{L}$, and oil and Fat $10 \mathrm{mg} / \mathrm{L}$. Characteristics of water samples (physical and chemical) taken at each sampling site were presented in Table 2; which includes 8 parameters ( $\mathrm{pH}$, temperature, total suspended solids (TSS), total dissolved solids (TDS), chemical oxygen demand (COD), dissolved oxygen (DO), $\mathrm{N}$ total, and Ptotal).

The collected water samples showed that $\mathrm{pH}$ values at almost all samples still met the quality standards ( $\mathrm{pH}$ 6-9), but only the CW6 sample had a low pH $(3,2)$. Sampling sate of CW6 was a new fish pond opened in swampy-land with acidic water conditions. The total suspended solids (TSS) in several locations exceeded the quality standard of $50 \mathrm{mg} / \mathrm{L}$ (CW1, SW11, SW 14, RPKIB, RPKIK, RPPI, RPBKN, and RPBrimob), with the highest TSS value was sample of SW11 (178 mg/L), while the TSS value of other locations were below the standard, ranged from 6 to 48 $\mathrm{mg} / \mathrm{L}$ ). The concentration of total dissolved solids (TDS) ranged from 39 to $545 \mathrm{mg} / \mathrm{L}$. High TDS values were observed at CW locations (280 to $545 \mathrm{mg} / \mathrm{L}$ ), and the 
lowest was measured in SW15 sample (39 mg/L), followed by OPI Lake $(47 \mathrm{mg} / \mathrm{L})$ and RP IBA $(59 \mathrm{mg} / \mathrm{L})$. The other locations showed TDS values ranged from 89 to $223 \mathrm{mg} / \mathrm{L}$. All of these values are still below the specified quality standard $(1,000 \mathrm{mg} / \mathrm{L})$. Sample collected from OPI Lake had high DO value $(8.78 \mathrm{mg} / \mathrm{L})$ while the other locations were below the quality standard value that has to meets a minimum of $6 \mathrm{mg} / \mathrm{L}$, ranged from 0.49 to $5.84 \mathrm{mg} / \mathrm{L}$. For surface water, the maximum limit $(10 \mathrm{mg} / \mathrm{L})$. The results showed that COD values of all samples exceeded the maximum limit of the quality standard value, with the highest COD values was the sample collected from cattle farms, ranged from 198 to $222 \mathrm{mg} / \mathrm{L}$, while the COD value of other locations ranged from 13 to $91 \mathrm{mg} / \mathrm{L}$.

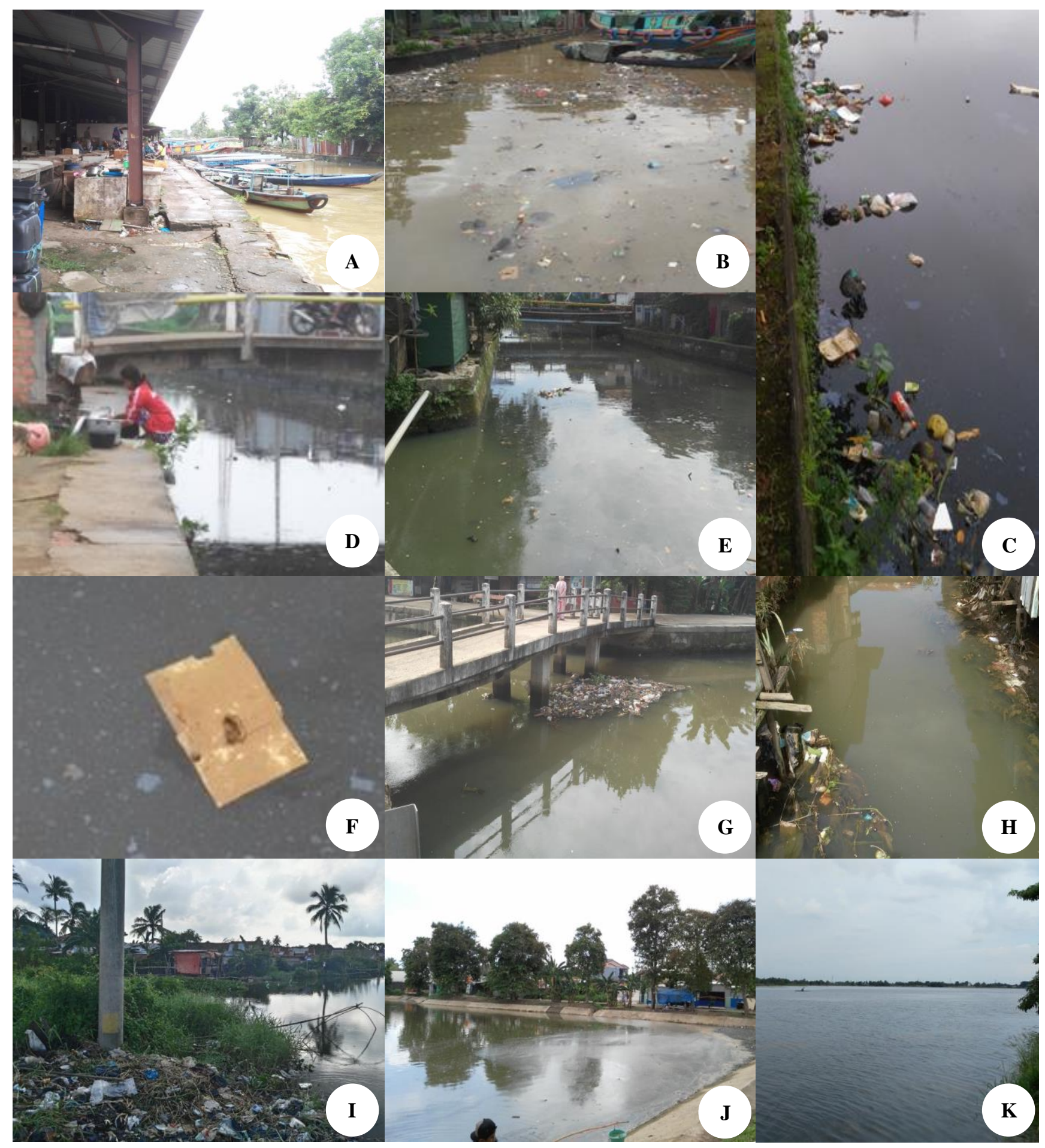

Figure 2. Some of the sampling sites in this study, in Palembang City, South Sumatra, Indonesia. Locations of SW11 and SW12 sampling sites (A and B); SW6, SW9 and SW5 sampling sites (C, D, and E); SW13, SW3 and SW8 sampling sites (F, G, and H); RPKM (I), RPSH (J) and RPJSC (K). 
Table 1. Characteristics of water sampling sites in Palembang City, Indonesia

\begin{tabular}{|c|c|}
\hline Site ID & Sampling sites characteristics \\
\hline CW1-CW3 & Cattle and fish farms, closed pond \\
\hline CW4 & Small-scale poultry farm closed pond \\
\hline CW5 & Cattle farms, fish farms, closed pond. \\
\hline CW6 & Originally swamp area, new open pond, low $\mathrm{pH}$ \\
\hline CW7 & Cattle farms, fish farms, closed pond \\
\hline SW1 & The residential settlement, sewage overflowed. \\
\hline SW2 & The residential settlement, small-scale poultry farm, sewage overflowed \\
\hline SW3 & Densely population settlement, domestic solid and liquid wastes disposal, affected by the daily tidal stream \\
\hline SW 4 & Domestic solid and liquid wastes disposal, affected by the daily tidal stream \\
\hline SW5 & $\begin{array}{l}\text { Poor sanitation, domestic wastes disposal, sewage overflowed, FOG, presence of animal carcasses and animal feces, } \\
\text { affected by the daily tidal stream }\end{array}$ \\
\hline RPSH1-2 & Human-made closed pond, moderately algal growth, sewage overflowed, smelly water \\
\hline RPSH3 & $\begin{array}{l}\text { Human-made closed pond, relatively transparent water, domestic wastes disposal, sewage overflow, residential and } \\
\text { road runoff }\end{array}$ \\
\hline SW6 & Moderately algae bloom, domestic wastes disposal, sewage overflow and affected by daily tidal \\
\hline SW7 & $\begin{array}{l}\text { Home scale cattle farm, faulty septic tank, sewage overflow, moderately algae bloom, domestic wastes disposal and } \\
\text { affected by daily tidal }\end{array}$ \\
\hline SW8-9 & Moderately algae bloom, domestic wastes disposal, sewage overflow and affected by daily tidal \\
\hline SW 10 & No solid and liquid domestic waste disposal, flow and shallow water stream \\
\hline SW11-12 & $\begin{array}{l}\text { Sekanak traditional market, dense population, domestic wastes disposal, sewage overflow, data were collected before } \\
\text { the renovation works were started }\end{array}$ \\
\hline SW13-14 & City business area, dense population, near hotels, food street, and shopping malls, sewage overflow \\
\hline RPKM & $\begin{array}{l}\text { Natural pond connected to marsh ecosystem, poor sanitation area, domestic waste disposal, many trees (open area), } \\
\text { residential area }\end{array}$ \\
\hline RPKIB & Human-made, sport and recreational spots, city garden, residential area, flow water, surrounded by trees \\
\hline RPKIK & Human-made, recreational spot, city garden, residential area, closed pond, surrounded by trees \\
\hline SW15 & Sekanak traditional market, dense population, domestic wastes, sewage overflow \\
\hline RPPI & $\begin{array}{l}\text { Human-made, less dense population, road runoff, shopping mall, ponds with continuous aeration, stagnant throughout } \\
\text { the year, less domestic waste disposal, fewer trees (open area), shallow water pond, data were collected before the } \\
\text { renovation works were started }\end{array}$ \\
\hline RP Polda & $\begin{array}{l}\text { Human-made, less dense population, road runoff, shopping mall, stagnant throughout the year, sewage overflow, } \\
\text { fewer trees (open area) }\end{array}$ \\
\hline RPAst1-2 & Human-made, Poor sanitation, dense population, closed pond \\
\hline RPSP & $\begin{array}{l}\text { Human-made connected to marsh ecosystem, poor sanitation, dense population, stagnant throughout the year, less } \\
\text { domestic waste disposal, fewer trees (open area), shallow water pond }\end{array}$ \\
\hline RPSM & $\begin{array}{l}\text { Human-made connected to marsh ecosystem, less dense population, stagnant throughout the year, less domestic waste } \\
\text { disposal, fewer trees (open area), shallow water pond }\end{array}$ \\
\hline RPTS & $\begin{array}{l}\text { Natural pond connected to marsh ecosystem, less dense population, stagnant throughout the year, domestic waste } \\
\text { disposal, fewer trees (open area), shallow water pond, wastes of tempeh industry }\end{array}$ \\
\hline RPSB & $\begin{array}{l}\text { Human-made, dense population, stagnant throughout the year, close to the highway, domestic waste disposal, many } \\
\text { trees (open area), deep water pond }\end{array}$ \\
\hline RPIBA & $\begin{array}{l}\text { Human-made, less dense population, stagnant throughout the year, no domestic waste disposal, very few trees (open } \\
\text { area), shallow water pond, a newly re-excavated dam }\end{array}$ \\
\hline RPBKN & $\begin{array}{l}\text { Human-made, poor sanitation area, far from the highway, stagnant throughout the year, solid domestic waste disposal, } \\
\text { almost no trees, traditional market, deepwater pond }\end{array}$ \\
\hline RPJSC & Natural swampy pond, part of the sports area, no domestic wastes disposal, stagnant throughout the year. \\
\hline OPI Lake & Human-made, closed pond, sedimentation swamp pond, affected by traditional market runoff and domestic wastes disposal \\
\hline RP Brimob & $\begin{array}{l}\text { Natural pond connected to marsh ecosystem, recently renovated, data were collected before the renovation works } \\
\text { were started }\end{array}$ \\
\hline
\end{tabular}

Nitrogen total of the samples ranged from $<0.10$ to 4.86 $\mathrm{mg} / \mathrm{L}$. All samples from cattle farms $(\mathrm{CW})$ showed high Ntot values $(2.75-4.84 \mathrm{mg} / \mathrm{L})$, while the lowest was the RPTS sample. Ntot values from other samples ranged from 1.32 to $4.23 \mathrm{mg} / \mathrm{L}$. The Phosphate total (Ptot) of the samples ranged from $0.72 \mathrm{mg} / \mathrm{L}$ (the highest was $\mathrm{CW} 1$ ) to
$<0.01 \mathrm{mg} / \mathrm{L}$ (the lowest was OPI Lake). The maximum allowable level of phosphate content based on the quality standard is set at $0.2 \mathrm{mg} / \mathrm{L}$. The concentrations of Ptot from CW samples were mostly high (0.33-0.72 mg/L). The other locations have the Ptot values below the standards limit are RPKIB and RPKIK (0.09-0.1 mg/L), followed by RPPI and 
RP Polda (both were $0.01 \mathrm{mg} / \mathrm{L}$ ). Results of the total coliform (TC) of samples collected from several aquatic environments showed TC ranged from 0 to $>1600$ MPN/100 mL. Sampling sites with the $\geq 1.600 .000$ MPN/100 mL were TC of SW1, SW8, SW11, SW12, SW13, and SW14 were $\geq 1.600 .000 \mathrm{MPN} / 100 \mathrm{~mL}$ (Table 3.) The South Sumatra Governor Regulation No 16 of 2005 for river water quality standard limited Coliform total at 10.000 MPN/100 mL.

The validation results indicated the presence of $E$. coli was negative in the samples of SW3, RPPI, RPTS, RPSB, RPIBA, and RPOPI. Colonies that showed positive bluegreen metallic in EMBA media $(E$. coli) were subcultured several times to obtain pure isolates of $E$. coli and to be used will be further tested for antibiotics susceptibility test. To confirm the species of bacteria so that the IMViC test was carried out include indole test, methyl red test, VogesProskauer test, and citrate test. E. coli bacteria will produce indol and positive of methyl red positive as well as VogesProskauer and negative of citrate tests in the IMViC test. In general, fecal coliform consists of three bacterial genera, including Klebsiella pneumonia, E. coli, and Enterobacter $s p$. All of these three bacteria ferment lactose and produce acids and gases at $44^{\circ} \mathrm{C}$; however, only the $E$. coli colonies show a green metallic color on EMB agar so that $E$. coli can be differentiated from other genera. This, study only focuses on exploring the multiresistant antibiotics $E$. coli. A list of samples containing E. coli presented in Table 3.

Table 2. Physical and chemical characteristics of water samples collected from 41 sampling sites in Palembang City, Indonesia

\begin{tabular}{|c|c|c|c|c|c|c|c|c|c|c|}
\hline Samples codes & X_COR & Y_COR & PH & $\begin{array}{l}\text { Temp } \\
\left({ }^{\circ} \mathrm{C}\right)\end{array}$ & $\begin{array}{c}\text { DO } \\
\text { (ppm) }\end{array}$ & $\begin{array}{c}\text { TDS } \\
(\mathrm{mg} / \mathrm{L})\end{array}$ & COD & Ntot & Ptot & TSS \\
\hline CW 1 & 467261 & 9671863 & 7.6 & 29.2 & 0.65 & 545 & 222 & 4.86 & 0.72 & 68 \\
\hline CW 2 & 467261 & 9671863 & 7.2 & 30.2 & 0.70 & 458 & 201 & 4.52 & 0.64 & 22 \\
\hline CW 3 & 467261 & 9671863 & 7.1 & 30.3 & 0.75 & 414 & 201 & 4.32 & 0.58 & 35 \\
\hline CW 4 & 467261 & 9671863 & 7.4 & 30.4 & 0.86 & 280 & 110 & 2.72 & 0.41 & 25 \\
\hline CW 5 & 467261 & 9671863 & 7.2 & 30.5 & 0.77 & 335 & 142 & 3.12 & 0.33 & 32 \\
\hline CW 6 & 467261 & 9671863 & 3.2 & 30.6 & 0.76 & 333 & 133 & 3.56 & 0.44 & 7 \\
\hline CW 7 & 467261 & 9671863 & 6.4 & 30.7 & 0.49 & 440 & 198 & 4.25 & 0.51 & 21 \\
\hline SW 1 & 469686 & 9670699 & 6.7 & 30.8 & 0.93 & 152 & 55 & 3.12 & 0.22 & 19 \\
\hline SW 2 & 469947 & 9670519 & 7 & 30.9 & 4.17 & 168 & 60 & 3.24 & 0.29 & 23 \\
\hline SW 3 & 470122 & 9670472 & 7.3 & 30.10 & 4.95 & 161 & 37 & 3.88 & 0.56 & 51 \\
\hline SW 4 & 470811 & 9670498 & 7.4 & 30.11 & 4.24 & 186 & 83 & 3.57 & 0.37 & 13 \\
\hline SW 5 & 470502 & 9670338 & 7.5 & 30.12 & 2.64 & 203 & 60 & 4.23 & 0.41 & 25 \\
\hline RPSH 1 & 470299 & 9671690 & 7.4 & 30.13 & 5.69 & 196 & 61 & 3.77 & 0.29 & 48 \\
\hline RPSH 2 & 470271 & 9671570 & 7.2 & 30.14 & 4.61 & 223 & 91 & 2.97 & 0.34 & 8 \\
\hline RPSH 3 & 470318 & 9671612 & 7.1 & 30.15 & 4.65 & 113 & 83 & 4.46 & 0.49 & 19 \\
\hline SW 6 & 469088 & 9670140 & 7.4 & 30.16 & 5.84 & 180 & 67 & 4.38 & 0.34 & 18 \\
\hline SW 7 & 468802 & 9670053 & 7.3 & 30.17 & 2.98 & 171 & 35 & 3.11 & 0.73 & 17 \\
\hline SW 8 & 470439 & 9670907 & 7.4 & 30.18 & 4.13 & 192 & 41 & 3.42 & 0.61 & 16 \\
\hline SW 9 & 469413 & 9670034 & 7.4 & 30.19 & 5.84 & 181 & 37 & 3.18 & 0.48 & 18 \\
\hline SW 10 & 471027 & 9671525 & 7.5 & 30.20 & 5.84 & 195 & 44 & 3.26 & 0.72 & 10 \\
\hline SW 11 & 473035 & 9668979 & 7.3 & 30.21 & 5.02 & 154 & 30 & 3.71 & 0.75 & 178 \\
\hline SW 12 & 472870 & 9669367 & 7.4 & 30.22 & 5.28 & 176 & 33 & 3.89 & 0.84 & 10 \\
\hline SW 13 & 472320 & 9670197 & 7.3 & 30.23 & 4.84 & 201 & 52 & 2.28 & 0.73 & 10 \\
\hline SW 14 & 471587 & 9671001 & 7.4 & 30.24 & 4.84 & 189 & 48 & 3.16 & 0.48 & 51 \\
\hline RPKM & 470899 & 9668904 & 7.6 & 27.5 & 3.46 & 166 & 45 & 3.12 & 0.22 & 33 \\
\hline RPKIB & 471752 & 9669524 & 7.3 & 27.7 & 3.31 & 89 & 47 & 4.82 & 0.09 & 62 \\
\hline RPKIK & 471402 & 9669654 & 7.3 & 27.4 & 3.31 & 98 & 40 & 4.55 & 0.1 & 54 \\
\hline SW 15 & 472825 & 9669481 & 7.3 & 28.8 & 3.05 & 39 & 37 & 4.22 & 0.89 & 48 \\
\hline RPPI & 471810 & 9670665 & 7.4 & 27.5 & 4.09 & 125 & 41 & 4.58 & 0.01 & 74 \\
\hline RPPo & 470813 & 9672747 & 7.4 & 27.2 & 1.6 & 145 & 31 & 3.36 & 0.12 & 39 \\
\hline RPAst 1 & 471592 & 9673759 & 7.5 & 28 & 2.23 & 147 & 30 & 4.15 & 0.18 & 43 \\
\hline RPAst 2 & 471659 & 9673682 & 7.4 & 27.4 & 1.49 & 181 & 30 & 3.39 & 0.08 & 39 \\
\hline RPSP & 473007 & 9674227 & 7.9 & 28.5 & 1.26 & 113 & 80 & 2.52 & 0.02 & 32 \\
\hline RPSM & 475217 & 9674588 & 7.7 & 28.8 & 5.13 & 91 & 48 & 1.12 & 0.09 & 11 \\
\hline RPTS & 475381 & 9675425 & 7.5 & 31.7 & 1.12 & 128 & 13 & $<0.1$ & 0.12 & 47 \\
\hline RPSB & 476833 & 9677224 & 7.7 & 30.7 & 4.76 & 121 & 31 & 1.32 & 0.11 & 22 \\
\hline RPIBA & 473842 & 9672173 & 7.9 & 30.2 & 2.05 & 59 & 15 & 1.32 & 0.08 & 45 \\
\hline RPBKN & 474765 & 9668380 & 7.7 & 30 & 3.98 & 113 & 41 & 4.22 & 0.09 & 60 \\
\hline RPJSC & 477411 & 9666737 & 5.1 & 29 & 5.91 & 140 & 13 & 2.16 & 0.06 & 6 \\
\hline OPI Lake & 476498 & 9663078 & 7.3 & 29.9 & 8.78 & 47 & 25 & 3.13 & $<0.1$ & 19 \\
\hline RPBRM & 469717 & 9669569 & 7.4 & 31.8 & 3.41 & 112 & 36 & 3.12 & 0.29 & 51 \\
\hline
\end{tabular}

Note: *) NT: Not tested; CW: Cattle Farm ; SW: Sekanak watershed; RP: Retention pond; RPSH: RP_near St Khodijah Hospital; RPKM: Kemang Manis. RPKIB: Kambang Iwak Besak; RPKIK: Kambang Iwak Kecik; RPPI: Palembang Icon; RPAst: RP Kemuning; RPSP: Seduduk Putih; RPSM: Sapta Marga; RPTS; Tanjung Sari; RPSM: Sematang borang; RPIBA/Bangau; RPBKN; RPJSC: Jaka Baring Sport Center; OPI Lake: Ogan Permata Indah; RPBrimob. 
Table 3. Most Probable Number (MPN) and IMViC of water samples

\begin{tabular}{|c|c|c|c|}
\hline Codes & $\begin{array}{l}\text { Total coliform } \\
\text { (MPN/100 mL) }\end{array}$ & $\begin{array}{l}\text { E. coli } \\
\text { (MPN/100 } \\
\text { mL) }\end{array}$ & IMViC Result \\
\hline CW 1 & $4.9 \times 10^{4}$ & $2.0 \times 10^{3}$ & (+) Escherichia coli \\
\hline CW 2 & $1.4 \times 10^{4}$ & -ve & -ve \\
\hline CW 3 & $3 \times 10^{5}$ & $4.2 \times 10^{4}$ & (+) Escherichia coli \\
\hline CW 4 & $1.7 \times 10^{5}$ & $1.6 \times 10^{4}$ & (+) Escherichia coli \\
\hline CW 5 & $3.5 \times 10^{5}$ & $2.0 \times 10^{3}$ & (+) Escherichia coli \\
\hline CW 6 & -ve & -ve & $-\mathrm{ve}$ \\
\hline CW 7 & $9.2 \times 10^{5}$ & $1.7 \times 10^{4}$ & (+) Escherichia coli \\
\hline SW 1 & $\geq 1.6 \times 10^{5}$ & $\geq 1.6 \times 10^{4}$ & (+) Escherichia coli \\
\hline SW 2 & $1.6 \times 10^{5}$ & $7.9 \times 10^{4}$ & (+) Escherichia coli \\
\hline SW 3 & $9.2 \times 10^{5}$ & $2.0 \times 10^{3}$ & -ve \\
\hline SW 4 & $3 \times 10^{5}$ & $3.4 \times 10^{4}$ & (+) Escherichia coli \\
\hline SW 5 & $3 \times 10^{5}$ & $1.7 \times 10^{4}$ & (+) Escherichia coli \\
\hline RPSH 1 & $7.9 \times 10^{4}$ & -ve & -ve \\
\hline RPSH 2 & $5.4 \times 10^{5}$ & $1.7 \times 10^{3}$ & (+) Escherichia coli \\
\hline RPSH 3 & $1.6 \times 10^{5}$ & $9.2 \times 10^{3}$ & (+) Escherichia coli \\
\hline SW 6 & $7.9 \times 10^{5}$ & $7.0 \times 10^{3}$ & (+) Escherichia coli \\
\hline SW 7 & $2.4 \times 10^{5}$ & $1.7 \times 10^{4}$ & (+) Escherichia coli \\
\hline SW 8 & $\geq 1.6 \times 10^{5}$ & $1.6 \times 10^{4}$ & (+) Escherichia coli \\
\hline SW 9 & $1.6 \times 10^{5}$ & $1.6 \times 10^{4}$ & (+) Escherichia coli \\
\hline SW 10 & $9.2 \times 10^{4}$ & $1.6 \times 10^{3}$ & (+) Escherichia coli \\
\hline SW 11 & $\geq 1.6 \times 10^{5}$ & $\geq 1.6 \times 10^{4}$ & (+) Escherichia coli \\
\hline SW 12 & $\geq 1.6 \times 10^{5}$ & $\geq 1.6 \times 10^{4}$ & (+) Escherichia coli \\
\hline SW 13 & $\geq 1.6 \times 10^{5}$ & $\geq 1.6 \times 10^{4}$ & (+) Escherichia coli \\
\hline SW 14 & $\geq 1.6 \times 10^{5}$ & $\geq 1.6 \times 10^{4}$ & (+) Escherichia coli \\
\hline RPKM & $1.7 \times 10^{5}$ & $4.0 \times 10^{3}$ & (+) Escherichia coli \\
\hline RPKIB & $2.0 \times 10^{3}$ & $2.0 \times 10^{2}$ & (+) Escherichia coli \\
\hline RPKIK & $9.2 \times 10^{5}$ & $2.0 \times 10^{3}$ & (+) Escherichia coli \\
\hline SW 15 & $2.2 \times 10^{4}$ & $7.0 \times 10^{3}$ & (+) Escherichia coli \\
\hline RPPI & $1.7 \times 10^{5}$ & $3.4 \times 10^{4}$ & -ve \\
\hline RP Polda & $3 \times 10^{5}$ & $1.7 \times 10^{4}$ & (+) Escherichia coli \\
\hline RPAst 1 & $1.7 \times 10^{4}$ & $2.0 \times 10^{3}$ & (+) Escherichia coli \\
\hline RPAst 2 & $5.4 \times 10^{5}$ & $1.3 \times 10^{4}$ & (+) Escherichia coli \\
\hline RPSP & $5.4 \times 10^{5}$ & $7.0 \times 10^{4}$ & (+) Escherichia coli \\
\hline RPSM & $9.2 \times 10^{3}$ & -ve & -ve \\
\hline RPTS & $9.2 \times 10^{5}$ & $1.6 \times 10^{4}$ & -ve \\
\hline RPSB & $1.7 \times 10^{5}$ & $3.4 \times 10^{4}$ & -ve \\
\hline RPIBA & $3.3 \times 10^{3}$ & -ve & -ve \\
\hline RPBKN & $2.7 \times 10^{4}$ & $4.0 \times 10^{3}$ & (+) Escherichia coli \\
\hline RPJSC & -ve & -ve & -ve \\
\hline OPI Lake & $2.3 \times 10^{4}$ & $8.0 \times 10^{3}$ & -ve \\
\hline $\begin{array}{l}\text { RP } \\
\text { Brimob }\end{array}$ & $\mathrm{NT}^{*}$ & $\mathrm{NT}^{*}$ & -ve \\
\hline
\end{tabular}

Note: *) NT: Not tested; CW: Cattle Farm ; SW: Sekanak watershed; RP: Retention pond; RPSH: RP_near St Khodijah Hospital; RPKM: Kemang Manis. RPKIB: Kambang Iwak Besak; RPKIK: Kambang Iwak Kecik; RPPI: Palembang Icon; RPAst: RP Kemuning; RPSP: Seduduk Putih; RPSM: Sapta Marga; RPTS; Tanjung Sari; RPSM: Sematang borang; RPIBA/Bangau; RPBKN; RPJSC: Jaka Baring Sport Center; OPI Lake: Ogan Permata Indah; RP Brimob.

There were 1422 colonies from 41 sampling sites in this study. Based on the results of the verification test, it showed $22 \%$ of those colonies were positively E. coli (n: $307) ; 15 \%$ of $E$. coli strains were susceptible to antibiotics. Amongst those of $22 \%$ isolates, $8 \%$ were collected from cattle farms, $18 \%$ were isolated from retention ponds, and
Table 4. Susceptibility of Escherichia coli strains collected from sampling sites to several antibiotics

\begin{tabular}{|c|c|c|c|c|c|c|c|c|c|}
\hline \multirow{2}{*}{ Sample codes } & \multicolumn{9}{|c|}{ Antibiotics susceptibility*) } \\
\hline & Tbr & Amp & Tet & Can & Сур & Cot & Cef & Gen & Chm \\
\hline Ec_CW 1 & $\mathrm{~S}$ & $\mathrm{~S}$ & $\mathrm{R}$ & I & $\mathrm{S}$ & $\mathrm{S}$ & $\mathrm{S}$ & $\mathrm{S}$ & $\mathrm{S}$ \\
\hline Ec_CW 3 & $S$ & $\mathrm{~S}$ & $\mathrm{R}$ & I & $\mathrm{S}$ & $\mathrm{S}$ & $\mathrm{S}$ & $\mathrm{S}$ & $\mathrm{S}$ \\
\hline Ec_CW 4 & $\mathrm{~S}$ & $\mathrm{~S}$ & $\mathrm{R}$ & $\mathrm{S}$ & $\mathrm{S}$ & $\mathrm{S}$ & $\mathrm{S}$ & $\mathrm{S}$ & $\mathrm{S}$ \\
\hline Ec_CW 5 & S & S & $\mathrm{R}$ & $\mathrm{S}$ & $\mathrm{S}$ & I & I & $\mathrm{S}$ & $\mathrm{S}$ \\
\hline Ec_CW 7 & $\mathrm{R}$ & $\mathrm{S}$ & $\mathrm{R}$ & I & $\mathrm{S}$ & I & $\mathrm{S}$ & $\mathrm{S}$ & $\mathrm{S}$ \\
\hline Ec SW1 & $\mathrm{S}$ & $\mathrm{R}$ & $\mathrm{R}$ & $\mathrm{S}$ & $\mathrm{S}$ & $\mathrm{S}$ & $\mathrm{S}$ & $\mathrm{S}$ & $\mathrm{S}$ \\
\hline Ec_SW2 & $\mathrm{S}$ & $\mathrm{R}$ & $\mathrm{R}$ & I & $S$ & $\mathrm{~S}$ & $\mathrm{~S}$ & $\mathrm{~S}$ & $S$ \\
\hline Ec_SW4 & $\mathrm{R}$ & $\mathrm{R}$ & $\mathrm{R}$ & $\mathrm{R}$ & $S$ & I & $S$ & $\mathrm{~S}$ & $S$ \\
\hline Ec_SW5 & $\mathrm{R}$ & $\mathrm{R}$ & $\mathrm{R}$ & $\mathrm{S}$ & $\mathrm{S}$ & $\mathrm{R}$ & $\mathrm{R}$ & $\mathrm{S}$ & $\mathrm{R}$ \\
\hline Ec_SW6 & $\mathrm{R}$ & $\mathrm{R}$ & $\mathrm{R}$ & $S$ & $S$ & I & $\mathrm{R}$ & $\mathrm{S}$ & $\mathrm{S}$ \\
\hline Ec_SW7 & $\mathrm{R}$ & $\mathrm{R}$ & $\mathrm{R}$ & I & $S$ & $\mathrm{~S}$ & $\mathrm{~S}$ & $\mathrm{~S}$ & $S$ \\
\hline Ec_SW8 & $\mathrm{R}$ & $\mathrm{R}$ & I & S & $S$ & S & $\mathrm{S}$ & I & $S$ \\
\hline Ec_SW9 & $\mathrm{R}$ & $\mathrm{R}$ & $\mathrm{R}$ & I & $S$ & I & I & I & $S$ \\
\hline Ec_SW10 & $S$ & $\mathrm{R}$ & I & $S$ & $S$ & I & I & $\mathrm{S}$ & $\mathrm{S}$ \\
\hline Ec_SW11 & $\mathrm{R}$ & $\mathrm{R}$ & $\mathrm{R}$ & I & $S$ & $S$ & I & I & $S$ \\
\hline Ec_SW12 & $\mathrm{R}$ & $\mathrm{R}$ & I & $\mathrm{R}$ & $\mathrm{R}$ & $\mathrm{R}$ & $\mathrm{R}$ & I & I \\
\hline Ec_SW13 & $\mathrm{R}$ & $\mathrm{R}$ & $S$ & $\mathrm{R}$ & $\mathrm{R}$ & $\mathrm{R}$ & I & I & I \\
\hline Ec_SW 15 & $\mathrm{R}$ & $\mathrm{R}$ & I & I & $S$ & $\mathrm{R}$ & $\mathrm{R}$ & I & $S$ \\
\hline Ec_SW14 & $\mathrm{R}$ & $\mathrm{R}$ & $\mathrm{R}$ & I & I & I & $S$ & I & I \\
\hline Ec_RPSH2 & $\mathrm{R}$ & $\mathrm{R}$ & $\mathrm{R}$ & $\mathrm{S}$ & $S$ & I & I & I & $S$ \\
\hline Ec_RPSH3 & $\mathrm{R}$ & $\mathrm{R}$ & $\mathrm{R}$ & $\mathrm{R}$ & $S$ & I & I & $\mathrm{S}$ & I \\
\hline Ec_RPKM & $\mathrm{R}$ & $\mathrm{R}$ & I & I & $S$ & I & I & I & I \\
\hline Ec_RPKIB & $\mathrm{R}$ & $\mathrm{R}$ & I & I & $S$ & I & $\mathrm{S}$ & $\mathrm{S}$ & $S$ \\
\hline Ec_RPKIK & $\mathrm{R}$ & $\mathrm{R}$ & I & $\mathrm{S}$ & $S$ & I & I & I & I \\
\hline Ec_RP Po & $\mathrm{R}$ & $\mathrm{R}$ & $\mathrm{R}$ & I & $S$ & I & I & I & $S$ \\
\hline Ec_RP_Ast 2 & $\mathrm{R}$ & $\mathrm{R}$ & $\mathrm{R}$ & S & $S$ & I & I & I & I \\
\hline Ec_RPTS & $\mathrm{R}$ & $\mathrm{R}$ & $\mathrm{R}$ & I & $S$ & I & I & I & I \\
\hline Ec_RPBKN & $\mathrm{R}$ & $\mathrm{R}$ & $\mathrm{R}$ & $\mathrm{I}$ & $\mathrm{I}$ & I & I & $\mathrm{I}$ & I \\
\hline
\end{tabular}

Note: ${ }^{*}$ R: Resistant, I: Intermediete, S: Sensitive, Tbr: Tobramicin, Amp: Ampicillin, Tey: Tetracyclin, Can: Kanamycin, Cyp: Ciprofloxacin, Cot: Cotrimoxazole, Cfx: Cefixime, Gen: Gentamycin, Chm: Chloramphenicol

$74 \%$ were isolated from Sekanak River watersheds and its tributaries, canals, creeks, and channels. Antibiotic susceptibility test was carried out using the disk diffusion method against $E$. coli strains that had been grown on the Mueller-Hinton Agar. The antibiotic inhibitory zone of $E$. coli strains from 41 locations in this study showed varying degrees of sensitivity to the various types of antibiotics used in the test. Bacteria tested were categorized as sensitive, intermediate and resistant based on their inhibitory scores according to the standard interpretation of inhibition zone diameters, which were determined by the Clinical Laboratory Standards Institute (CLSI, 2012). Isolates that showed $E$. coli $(+)$ were tested for antibiotics susceptibility to 9 antibiotics (tobramycin, ampicillin, tetracycline, kanamycin, ciprofloxacin, cotrimoxazole, cefixime, gentamycin, and chloramphenicol) (Table 4).

The results of antibiotics susceptibility test of the $E$. coli strains indicated that $75 \%$ of the E. coli strains were resistant to tobramycin, $82 \%$ to ampicillin, $71 \%$ to tetracycline, $14 \%$ to kanamycin, $7 \%$ to ciprofloxacin, $14 \%$ to cotrimoxazole, $14 \%$ to cefixime, and both $4 \%$ to gentamycin and chloramphenicol. The results indicated $25 \%$ of $E$. coli strains showed intermediate result to tetracycline, $50 \%$ to kanamycin, $7 \%$ to ciprofloxacin, $57 \%$ 
to cotrimoxazole, $46 \%$ to cefixime, $50 \%$ to gentamycin and $32 \%$ chloramphenicol, while sensitive results showed that $25 \%$ of E. coli sensitive to tobramycin, $18 \%$ to ampicillin, $4 \%$ to tetracycline, $36 \%$ to kanamycin, $86 \%$ to ciprofloxacin, $29 \%$ to cotrimoxazole, $39 \%$ to cefixime, $46 \%$ to gentamycin and $64 \%$ to chloramphenicol. Based on the percentage of resistant and intermediate sensitivity to multiple antibiotics, it was concluded that E. coli strains collected from RPSH3 were high resistance $E$. to multiple antibiotics followed by the other five high resistance strains, which were Ec_SW5, Ec_SW6, Ec_SW8, Ec_SW12, Ec_SW13, and Ec_RPSH3. The E. coli isolates with a high percentage for resistant to antibiotics and also showed intermediate response to multiple antibiotics were Ec_SW9, Ec_SW14, Ec_RPSH3, Ec_RPKM, Ec_RPBKN, and Ec_RPTS. Lastly, the sensitive E. coli strains to antibiotics ranged from $11 \%$ (the lowest which was the EC isolate from RPBKN that was coded as Ec_RPBKN) to 89\% (the highest was isolate Ec_CW4).

The E. coli strains from RPs and SWs showed lower sensitivity compared to those from CWs. E. coli strains collected from CWs mostly sensitive to antibiotics. This study showed that there were $E$. coli colonies grow in the clear zone of cefixime paper disk (Figure 3). Cefixime is known to have a bacteriostatic effect with the ability to inhibit bacterial growth and reproduction without killing the bacteria; therefore, there will be a clear zone, but the bacteria still grows in the inhibitory zone.

\section{Discussion}

This study showed that $E$. coli collected from several aquatic environments had high resistance to tobramycin, ampicillin, and tetracycline. It is in agreement with the result of Kozak et al. (2009) reported that $83 \%$ of E. coli isolated from swine were resistance to tetracycline, and $58 \%$ were multi-resistance. Resistance of $E$. coli to at least two classes of antimicrobial agents in $E$. coli has been frequently found in the environment (Von Baum and Marre, 2005; Young, 1993) and it has been estimated that $17.6 \%$ of the genes in E. coli has been acquired by horizontal transfer at a rate of $16 \mathrm{~kb} / \mathrm{Myr}$ (Lawrence and Ochman, 1998). Other studies also reported high rates of $E$. coli resistance to tetracycline and kanamycin $(81.4 \%)$, chloramphenicol (75.7\%), gentamycin (74.3\%), and ampicillin (72.9\%) (Alhaj et al. 2007). High rates of multiresistance $E$. coli may be caused by long term use of antibiotics, especially overuse of antibiotics to treat caused by $E$. coli. Fernandez et al. (2013) reported a correlation between the inappropriate use of antibiotics with the percentage of resistance to antibiotics in Manggarai and West Manggarai Regencies-East Nusa Tenggara Timur (NTT).

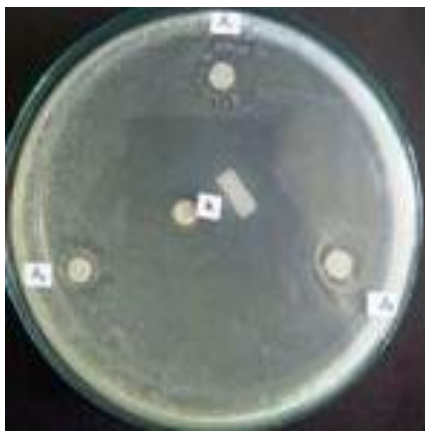

$\mathbf{A}$

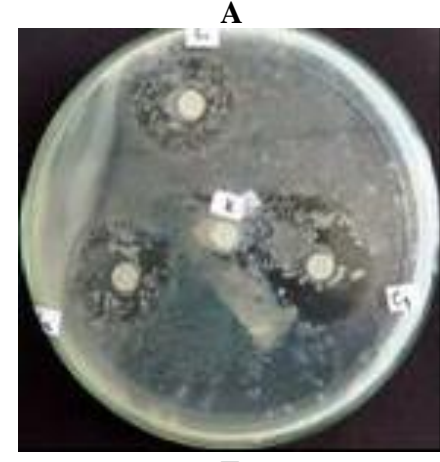

$\mathbf{E}$

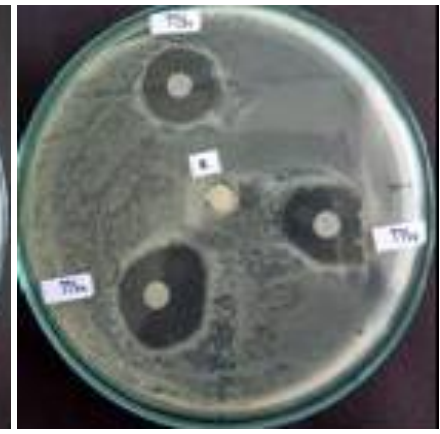

B

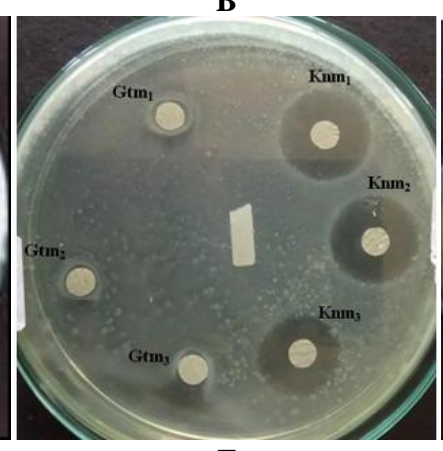

$\mathbf{F}$
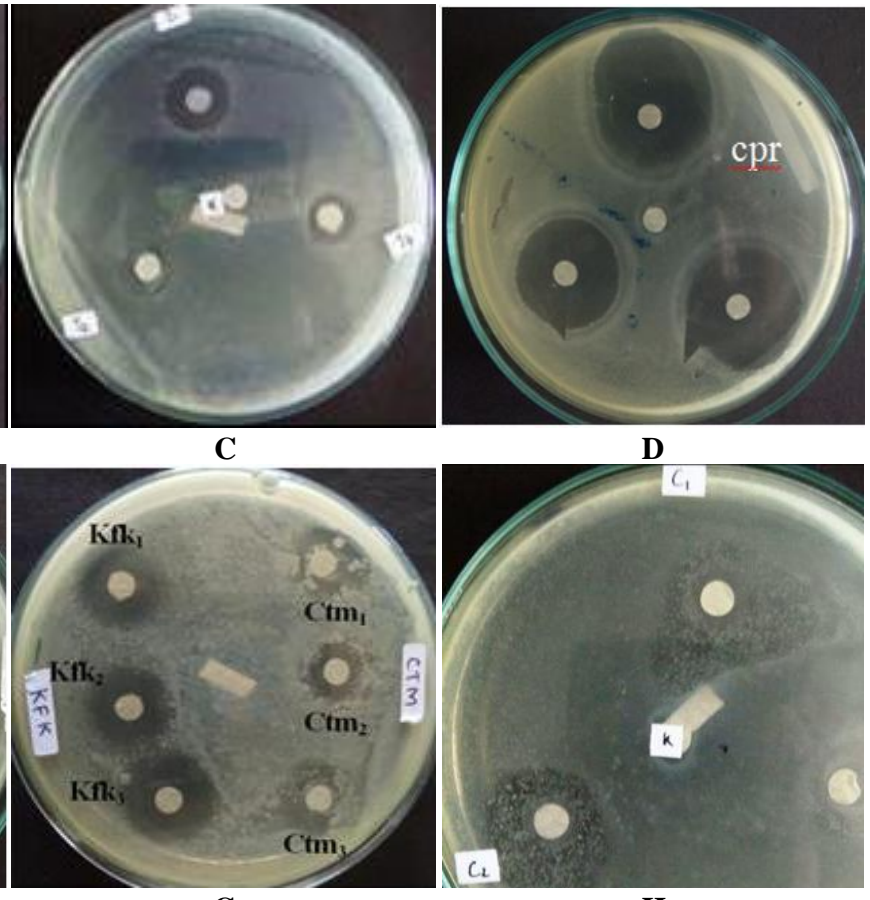

G

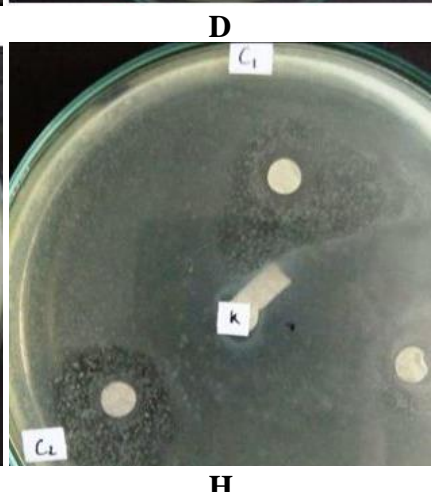

$\mathbf{H}$

Figure 3. Antibiotics susceptibility tests by Kirby-Bauer method against E. coli strains from the aquatic environment in Palembang City, Indonesia. A. Ampicilin, B. Tetracyclin, C. Tobramicyn, D. Ciprofloxacin, E. Cefixime, F. Gentamycin and Kanamycin, G. Chloramphenicol and Cotrimoxazole, H. Cefixime (SW14) 
The Indonesian Ministry of Health (2011) states that the widespread use of inappropriate antibiotics raises various problems and is a global threat to health, especially bacterial resistance to antibiotics. It has been suggested as one of the leading causes of $E$. coli resistance to ampicillin. Other studies carried out by Hadi et al. (2013) and Indonesian Ministry of Health (2005) in Indonesia reported that $43 \%$ of $2,494 \mathrm{E}$. coli isolates in Indonesia showed resistant to antibiotics, $34 \%$ were resistant to ampicillin and high rates of resistance to tetracycline due to uncontrollably used in medicine and animal husbandry.

The results of this study showed that the isolated $E$. coli was sensitive to ciprofloxacin (86\%) according to CLSI interpretation compared to 8 other antibiotics. However, several reports suggest the need for re-evaluation of CLSI breakpoints to prevent further development of fluoroquinolone resistance because several clinical isolates of $E$. coli showed reduced susceptibility to ciprofloxacin (Baudry-Simner et al. 2012) due to its irrational and inappropriate use (Ali et al. 2010). Kibret and Abera (2011) reported that ciprofloxacin was considered suitable for the empirical treatment of $E$. coli in northeast Ethiopia. Ciprofloxacin is one of fluorinated quinolones structurally related to nalidixic acid. It is a broad-spectrum antibiotic, more sensitive to gram-negative bacteria, and less effective against gram-positive bacteria (Campoli-Richards et al. 1988).

The results showed that E. coli isolated in this study were sensitive to gentamycin and chloramphenicol. Gentamycin belongs to the aminoglycoside group that has a broad spectrum, especially against gram-negative bacilli infections such as E. coli. Gentamycin has the ability to penetrate bacterial walls and bind ribosomes and interfere with the translation process and cause misreading in translating bacterial mRNA (Lintong et al. 2012). This study showed there was a bactericidal effect of cefixime to the isolated $E$. coli which was indicated by bacterial growth in the clear zone of cefixime paper disk. The bactericidal activities of cefixime to $E$. coli and $H$. influenza reported by Somekh et al. (1996). However, Arshad et al. (2012) reported that clinical isolates of E. coli and $S$. aureus had developed resistance to cefixime. A study by Ayatollahi et al. (2013) reported that $148 \mathrm{E}$. coli isolates from patients less than 18 years old showed high rates of the bacteria resistance to cefixime $(57.9 \%)$ and cotrimoxazole. Other study by Sah et al. (2016) in Nepal reported that $72.7 \%$ of E. coli resistance to ampicillin, followed by cephalexin (59.3\%), cotrimoxazole (45.2\%), cefixime (40\%), ceftriaxone (26.3\%), norfloxacin (25.9), ciprofloxacin (25\%), ofloxacin (20.7\%) nitrofurantoin (9.7\%), gentamycin $(9.4 \%)$ and amikacin $(8 \%)$. E. coli isolated from various sources including human, animals, environments, and other geographic locations showed dynamics and divers susceptibility towards antibiotics. The microbial dynamic changes require constant and regular monitoring for our future health hazards awareness; diseases spread prevention and ecosystem, wildlife and public health protection.
This study showed that sampling sites with low $\mathrm{pH}$ of water result in the negative presence of coliform and E. coli (CW6, pH 3,2 and RPJSC pH 5,1); however, in this study the correlation of $\mathrm{pH}$ and the total of both coliform and $E$. coli were not investigated. Low water $\mathrm{pH}$ can affect the respiratory capacity of aquatic organisms including bacteria, and can result in death due to asphyxia (Boyd, C. E. 1992). The highest coliform and E. coli numbers were observed in sampling sites with sewage overflows, near traditional markets, with domestic's wastes disposals (SW11, SW12, SW13, and SW14). Most of these sampling sites have high Ptot level. In the sampling sites connected to marsh ecosystem, shallow water streams, surrounded by trees (open green areas) showed high DO compared to other sites with fewer trees. The reduced population of trees and plants along riverbank and streams decreases shading which results in warmer water temperatures, it can lower dissolved oxygen concentrations indirectly because warm water holds less oxygen. Phosphorus is important for organisms, but in excessive concentration, it is harmful to most aquatic organisms such as decreasing DO levels of the water and causing the death of fish and many organisms. Turbidity is an indicator of the number of particles suspended in water that, in high concentrations can damage the habitats of fish and other aquatic organisms (APHA 1995).

In conclusion, this study indicated the evidence of resistant $E$. coli isolates to multiple antibiotics isolated from aquatic ecosystems in Palembang City, the response of the isolates towards the tested antibiotics were varied. In general, the results indicated that $82 \%$ of the isolates were resistant to ampicillin, $57 \%$ to tobramycin, and $71 \%$ to tetracycline. The isolates showed intermediate profile to kanamycin (50\%), 57\% to cotrimoxazole, $50 \%$ to cefixime, and $54 \%$ to gentamycin. These isolates still showed sensitivity towards ciprofloxacin (86\%) and chloramphenicol (61\%). The results also indicated that some of the sampling locations exceed the quality standard of water that has been regulated by the Governor South Sumatra and Indonesian Government. Finally, the E. coli isolated from different sources showed dynamics and divers susceptibility towards antibiotics. Therefore constant and regular monitoring is important for ensuring our future health hazards awareness; diseases spread prevention and ecosystem, wildlife and public health protection.

\section{ACKNOWLEDGEMENTS}

This research was supported and funded by The Ministry of Research, Technology, and Higher Education (Kemenristek Dikti), The Republic of Indonesia under the National Competitive Grants for The Basic Research of University's Higher Ranks (PDUPT) schema. The authors would like to express their gratitude to the Department of Biology and Chemistry, Faculty of Mathematics and Natural Sciences, Sriwijaya University, Palembang, Indonesia for their support. 


\section{REFERENCES}

Adegoke AA, Faleye AC, Singh G, Stenström TA. 2017. Antibioticresistant superbugs: Assessment of the interrelationship of occurrence in clinical settings and environmental niches. Molecules 22. DOI: 10.3390/molecules22010029.

Ali SQ, Zehra A, Naqvi BS, Shah S, Bushra R. 2010. Resistance pattern of ciprofloxacin against different pathogens. Oman Med J 25: 294 298. DOI: $10.5001 / o m j .2010 .85$.

Anderson ES. 1968. The ecology of transferable drug resistance in the enterobacteria. Annu Rev Microbiol 22: 131-180.

Andrews JM. 2001. Determination of minimum inhibitory concentrations. J Antimicrob Chemother 48: 5-16.

APHA. 1995. Standard Methods for the examination of water and wastewater. American Public Health Association, Washington DC

Arshad HM, Mohiuddin OA, Azmi MB. 2012. Comparative in vitro antibacterial analysis of different brands of cefixime against clinica isolates of Staphylococcus aureus and Escherichia coli. J Appl Pharm Sci 2: 109-113.

Ayatollahi J, Shahcheraghi SH, Akhondi R, Soluti S. 2013. Antibiotic Resistance Patterns of Escherichia coli Isolated from Children in Shahid Sadoughi Hospital of Yazd. Iran J Pediatr Hematol Oncol 3 78-82.

Ballantyne C. 2007. Strange but True: Antibacterial Products May Do More Harm Than Good Antibacterial soaps and other cleaners may actually be aiding in the development of superbacteria. [Internet]. https://www.scientificamerican.com/article/strange-but-trueantibacterial-products-may-do-more-harm-than-good/

Baquero F, Martinez J-L, Cantón R. 2008. Antibiotics and antibiotic resistance in water environments. Curr Opin Biotechnol 19: 260-265.

Baudry-Simner PJ, Singh A, Karlowsky JA, Hoban DJ, Zhanel GG. 2012. Mechanisms of reduced susceptibility to ciprofloxacin in Escherichia coli isolates from Canadian hospitals. Can J Infect Dis Med Microbio 23: 60-64.

Boyd CE. 1992. Water quality management for pond fish culture, 1st ed Elsevier, Amsterdam

Campoli-Richards DM, Monk JP, Price A, Benfield P, Todd PA, Ward A. 1988. Ciprofloxacin. Drugs 35: 373-447. DOI: $10.2165 / 00003495$ 198835040-00003

Cheng G, Hu Y, Yin Y. 2012. Functional screening of antibiotic resistance genes from human gut microbiota reveals a novel gene fusion. FEMS Microbiol Lett 336: 11-16. DOI: 10.1111/j.1574-6968.2012.02647.x

Cho S, Hiott LM, Barrett JB, McMillan EA, House SL, Humayoun SB Adams ES, Jackson CR, Frye JG. 2018. Prevalence and characterization of Escherichia coli isolated from the upper Oconee watershed in Northeast Georgia. PLoS One 13: 1-15. DOI: 10.1371/journal.pone.0197005

CLSI. 2010. Performance Standards for Antimicrobial Susceptibility Testing, Twenty-Second Informational Supplement [WWW Document]. URL https://clsi.org/

CLSI. 2012. Performance Standards for Antibiotic Disk Susceptibility Tests: Approved Standard, 11th ed. CLSI, Wayne PA.

Edge TA, Hill S. 2005. Occurrence of antibiotic resistance in Escherichia coli from surface waters and fecal pollution sources near Hamilton, Ontario. Can J Microbiol 51: 501-505. DOI: 10.1139/w05-028.

EUCAST. 2003. Determination of minimum inhibitory concentrations (MICs) of antibacterial agents by broth dilution. ESCMID, C 9: 1-7.

Fernandes B A M. 2013. Studi Penggunaan Antibiotik Tanpa Resep di Kabupaten Manggarai dan Manggarai Barat-NTT. J Ilmiah Mhs Univ Surabaya 2: 1-17.

Gillings M.R. 2013. Evolutionary consequences of antibiotic use for the resistome, mobilome, and microbial pangenome. Front Microbiol 4: 1-10. DOI: $10.3389 /$ fmicb.2013.00004.

Gorbach SL. 2001. Antimicrobial use in animal feed-time to stop.

Grabow WOK, Prozesky OW, Smith LS. 1974. Drug resistant coliforms call for review of water quality standards. Water Res 8: 1-9.

Guo M-T, Yuan Q-B, Yang J. 2015. Distinguishing effects of ultraviolet exposure and chlorination on the horizontal transfer of antibiotic resistance genes in municipal wastewater. Environ Sci Technol 49: $5771-5778$

Gutiérrez IR, Watanabe N, Harter T, Glaser B, Radke M. 2010. Effect of sulfonamide antibiotics on microbial diversity and activity in a Californian Mollic Haploxeralf. J Soils Sediments 10: 537-544. DOI 10.1007/s11368-009-0168-8.
Guyomard-Rabenirina S, Dartron C, Falord M, Sadikalay S, Ducat C, Richard V, Breurec S, Gros O, Talarmin A. 2017. Resistance to antimicrobial drugs in different surface waters and wastewaters of Guadeloupe. PLoS One 12: 1-17. DOI: 10.1371/journal.pone.0173155.

Hadi U, Kuntaman K, Qiptiyah M, Paraton H. 2013. Problem of Antibiotic Use and Antimicrobial Resistance in Indonesia: Are We Really Making Progress? Indon J Trop Infect Dis 4: 5. DOI: 10.20473/ijtid.v4i4.222.

Holmberg SD, Solomon SL, Blake PA. 1987. Health and economic impacts of antimicrobial resistance. Rev Infect Dis 9: 1065-1078.

Indonesian Ministry of Health. 2005. Antimicrobial Resistance, Antibiotic Usage and Infection Control. A Self-Assessment Program for Indonesian Hospitals. Directorate Generale of Medical Care, Indonesian Ministry of Health, Jakarta.

Jain A. 2019. Antibiotic resistant bacteria found in river water [internet]. The Hindu Bussiness https://www.thehindubusinessline.com/news/science/antibioticresistant-bacteria-found-in-river-water/article26570260.ece

Karlowsky JA, Jones ME, Thornsberry C, Friedland IR, Sahm DF. 2003. Trends in antimicrobial susceptibilities among Enterobacteriaceae isolated from hospitalized patients in the United States from 1998 to 2001. Antimicrob Agents Chemother 47: 1672-1680.

Khan GA, Berglund B, Khan KM, Lindgren PE, Fick J. 2013. Occurrence and Abundance of Antibiotics and Resistance Genes in Rivers, Canal and near Drug Formulation Facilities-A Study in Pakistan. PLoS One 8: 4-11. DOI: 10.1371/journal.pone.0062712.

Kibret M, Abera B. 2011. Antimicrobial susceptibility patterns of $E$. coli from clinical sources in northeast Ethiopia. Afr. Health Sci. 11: 40-45.

Kozak GK, Boerlin P, Janecko N, Reid-Smith RJ, Jardine C. 2009. Antimicrobial resistance in Escherichia coli isolates from Swine and wild small mammals in the proximity of swine farms and in natural environments in Ontario, Canada. Appl Environ Microbiol 75: 559. 566. DOI: 10.1128/AEM.01821-08

Kumar KC. Gupta S, Chander Y, Singh AK. 2005. Antibiotic use in agriculture and its impact on the terrestrial environment. Adv Agron 87: 1-54. DOI: 10.1016/S0065-2113(05)87001-4.

Lawrence JG, Ochman H. 1998. Molecular archaeology of the Escherichia coli genome. Proc Natl Acad Sci USA 95: 9413-9417.

Levy SB. 1998. The challenge of antibiotic resistance. Sci Am 278: 46-53.

Li D, Zeng S, He M, Gu AZ. 2016. Water disinfection byproducts induce antibiotic resistance-role of environmental pollutants in resistance phenomena. Environ Sci Technol 50: 3193-3201.

Li J, Cheng W, Xu L, Strong PJ, Chen H. 2015. Antibiotic-resistant genes and antibiotic-resistant bacteria in the effluent of urban residential areas, hospitals, and a municipal wastewater treatment plant system. Environ Sci Pollut Res 22: 4587-4596.

Li YX, Zhang XL, Li W, Lu XF, Liu B, Wang J. 2013. The residues and environmental risks of multiple veterinary antibiotics in animal faeces. Environ Monit Assess 185: 2211-2220. DOI: 10.1007/s10661012-2702-1.

Luo Y, Wang Q, Lu Q, Mu Q, Mao D. 2014. An ionic liquid facilitates the proliferation of antibiotic resistance genes mediated by class I integrons. Environ Sci Technol Lett 1: 266-270.

Martinez-Carballo E, González-Barreiro C, Scharf S, Gans O. 2007. Environmental monitoring study of selected veterinary antibiotics in animal manure and soils in Austria. Environ Pollut 148: 570-579.

Mishra M, Arukha AP, Patel AK, Behera N, Mohanta TK, Yadav D. 2018. Multi-drug resistant coliform: Water sanitary standards and health hazards. Front Pharmacol 9: 1-8. DOI: 10.3389/fphar.2018.00311.

Motoyama M, Nakagawa S, Tanoue R, Sato Y, Nomiyama K, Shinohara R. 2011. Residues of pharmaceutical products in recycled organic manure produced from sewage sludge and solid waste from livestock and relationship to their fermentation level. Chemosphere 84: 432438. DOI: $10.1016 /$ j.chemosphere.2011.03.048

Nwosu VC. 2001. Antibiotic resistance with particular reference to soil microorganisms. Res Microbiol 152: 421-430.

Pan X, Qiang Z, Ben W, Chen M. 2011. Residual veterinary antibiotics in swine manure from concentrated animal feeding operations in Shandong Province, China. Chemosphere 84: 695-700.

Pei R, Kim SC, Carlson KH, Pruden A. 2006. Effect of River Landscape on the sediment concentrations of antibiotics and corresponding antibiotic resistance genes (ARG). Water Res 40: 2427-2435. DOI: 10.1016/j.watres.2006.04.017 
Pruden A, Arabi M, Storteboom HN. 2012. Correlation between upstream human activities and riverine antibiotic resistance genes. Environ Sci Technol 46: 11541-11549.

Pruden A, Pei R, Storteboom H, Carlson KH. 2006. Antibiotic resistance genes as emerging contaminants: Studies in northern Colorado. Environ Sci Technol 40: 7445-7450. DOI: 10.1021/es0604131

Qiu Z, Yu Y, Chen Z, Jin M, Yang D, Zhao Z, Wang J, Shen Z, Wang X, Qian D, et al. 2012. Nanoalumina promotes the horizontal transfer of multiresistance genes mediated by plasmids across genera. Proc Natl Acad Sci USA 109: 4944-4949.

Review on Antimicrobial Resistance., 2014. Review on Antimicrobial Resistance, in: Antimicrobial Resistance: Tackling a Crisis for the Health and Wealth of Nations. Wellcome Trust \& HM Government, London.

Ribeiro AF, Laroche E, Hanin G, Fournier M, Quillet L, Dupont JP, Pawlak B. 2012. Antibiotic-resistant Escherichia coli in karstic systems: A biological indicator of the origin of fecal contamination? FEMS Microbiol Ecol 81, 267-280. DOI: 10.1111/j.15746941.2012.01382.x

Richmond MH. 1975. R factors in man and his environment. Microbiol. Am. Soc. Microbiol. Washington, DC 27-35.

Sah SK, Regmi S, Upreti AR, Pathak S. 2016. Antibiotic resistance patterns and evaluation of treatment in out-patients with urinary tract infections in Nepal. Int J Pharm Sci Res 7: 4626-4631.

Sarmah AK, Meyer MT, Boxall ABA. 2006. A global perspective on the use, sales, exposure pathways, occurrence, fate and effects of veterinary antibiotics (VAs) in the environment. Chemosphere 65: 725-759. DOI: 10.1016/j.chemosphere.2006.03.026

Sayah RS, Kaneene JB, Johnson Y, Miller R. 2005. Patterns of antimicrobial resistance observed in Escherichia coli isolates obtained from domestic-and wild-animal fecal samples, human septage, and surface water. Appl Environ Microbiol 71: 1394-1404.

Smith HW. 1970. Incidence in river water of Escherichia coli containing R factors. Nature 228: 1286-1288.

Smith HW. 1971. Incidence of R+ Escherichia coli in coastal bathing waters of Britain. Nature 234: 155.

SNI. 1991. Standar Nasional Indonesia (SNI 06-2483-1991); Metode pengujian kadar ortofosfat dan fosfat total dalam air dengan alat spektrofotometer secara asam askorbat. Badan Standardisasi Nasional, Jakarta. [Indonesian]

SNI.1992. Standar Nasional Indonesia (SNI 01- 2897-1992); Cara Uji Cemaran Mikroba. Badan Standardisasi Nasional, Jakarta. [Indonesian]

SNI. 2004. Standar Nasional Indonesia (SNI 06-6989.3-2004); Air dan air limbah- Bagian 3: Cara uji padatan tersuspensi total (Total Suspended Solid, TSS) secara gravimetri. Badan Standardisasi Nasional, Jakarta. [Indonesian]

SNI. 2008. Standar Nasional Indonesia (SNI 2897-2008); Metode pengujian cemaran mikroba dalam daging, telur dan susu, serta hasil olahannya. Badan Standardisasi Nasional, Jakarta. [Indonesian]

SNI. 2009. Standar Nasional Indonesia (SNI 6989.2:2009); Air dan air limbah- Bagian 2: Cara uji kebutuhan oksigen kimiawi (Chemical Oxygen Demand, COD) dengan refluks tertutup secara spektrofotometri. Badan Standardisasi Nasional, Jakarta. [Indonesian]

Somekh E, Heifetz L, Dan M, Poch F, Hafeli H, Tanai A. 1996. Penetration and bactericidal activity of cefixime in synovial fluid. Antimicrob. Agents Chemother 40: 1198-1200.

Taylor NGH, Verner-Jeffreys DW, Baker-Austin C. 2011. Aquatic systems: maintaining, mixing and mobilising antimicrobial resistance? Trends Ecol Evol 26: 278-284.

Urase T, Sato T. 2016. Quantitative monitoring of resistance in Escherichia coli to clinically important antimicrobials in an urban watershed. J Water Environ Technol 14: 341-349. DOI: 10.2965/jwet. 16-002

Von Baum H, Marre R. 2005. Antimicrobial resistance of Escherichia coli and therapeutic implications. Int J Med Microbiol 295: 503-511.

Wang Y, Lu J, Mao L, Li J, Yuan Z, Bond PL, Guo J. 2019. Antiepileptic drug carbamazepine promotes horizontal transfer of plasmid-borne multi-antibiotic resistance genes within and across bacterial genera. ISME J 13: 509-522. DOI: 10.1038/s41396-018-0275-X

WHO. 2014. Antimicrobial Resistance: Global Report on Surveillance 2014. WHO, Geneva, Switzerland.

Young H-K. 1993. Antimicrobial resistance spread in aquatic environments. J Antimicrob Chemother 31: 627-635.

Zhao L, Dong YH, Wang H. 2010. Residues of veterinary antibiotics in manures from feedlot livestock in eight provinces of China. Sci Total Environ 408: 1069-1075. 